\title{
Peripheral blood monocyte cytokine production and acute phase response in inflammatory bowel disease
}

\author{
M Z Mazlam, H J F Hodgson
}

\begin{abstract}
Cytokines released from activated mononuclear leukocytes are involved in triggering the acute phase response and many of the inflammatory manifestations of ulcerative colitis and Crohn's disease. The ability of circulating monocytes from patients with ulcerative colitis and Crohn's disease to generate the cytokines interleukin $1 \beta$ (IL $1 \beta$ ) and tumour necrosis factor alpha (TNF $\alpha$ ), both spontaneously and in response to stimulation by lipopolysaccharide, was compared. IL $1 \beta$ generation in response to lipopolysaccharide was significantly higher in Crohn's disease than in ulcerative colitis and normal controls, with a dramatic increase in patients with active disease. There was a significant reduction in lipopolysaccharide stimulated TNF $\alpha$ generation in ulcerative colitis patients compared with Crohn's disease and normal control subjects. IL $1 \beta$ and TNF $\alpha$ release correlated significantly with serum $C$ reactive protein and serum $\alpha_{1}$ acid glycoprotein in Crohn's disease. The ability of conditioned medium from monocytes in Crohn's disease to enhance release of $\alpha_{1}$ acid glycoprotein from the liver cell line HepG 2 in culture was assessed. There was a significant positive correlation between TNF $\alpha$ and IL $1 \beta$ presence in the supernatant and $\alpha_{1}$ acid glycoprotein production. The differences in the cytokine profile in patients with Crohn's disease compared with ulcerative colitis suggest an intrinsic difference in the ability to produce cytokines in patients with these two forms of inflammatory bowel disease, and may explain features such as the enhanced ability to generate a brisk $C$ reactive protein response in Crohn's disease.
\end{abstract}

Although most cases of inflammatory bowel disease can be classified as either ulcerative colitis or Crohn's disease on the basis of clinical and histopathological appearances, many of the inflammatory mechanisms involved at the tissue level in the two conditions are identical. ${ }^{\prime}$ Serum concentrations of correlates of inflammation such as $C$ reactive protein, $\alpha_{1}$ acid glycoprotein (or orosomucoid), and neutrophil elastase - have been extensively studied, largely because these objective parameters may help assess the inflammatory process either in individual patients or in clinical trials. This is particularly useful in Crohn's disease where the correlation between symptoms and the presence of inflammation may be poor. In comparisons between ulcerative colitis and Crohn's disease, differences in the circulating levels of some laboratory markers have emerged, even when attempts are made to compare patients with apparently similar degrees of clinical severity. Thus $\mathrm{C}$ reactive protein levels,' serum amyloid A associated protein,${ }^{3}$ and neutrophil elastase ${ }^{+}$are generally significantly higher during active Crohn's disease than during active ulcerative colitis, although $\alpha_{1}$ acid glycoprotein and $\alpha_{1}$-antichymotrypsin ${ }^{5}$ show a similar increase.

There may be relatively trivial explanations for the differences in serum levels of parameters of inflammation between the two conditions. For example, the lower elastase concentrations found in ulcerative colitis may merely reflect the more superficial distribution of inflammation, compared with Crohn's disease, and consequent loss of elastase released from polymorphonuclear leukocytes into the gut lumen rather than into the circulation. An alternative explanation is that these differences reflect differences in the nature of the inflammatory processes occurring in these two conditions. Differing inflammatory processes might reflect different aetiologies of ulcerative colitis and Crohn's disease; alternatively, even if the initiating factor for inflammatory bowel disease is the same, a differing genetic background might predispose to expression of a particular form of inflammatory response, resulting in development of one or other form of inflammatory bowel disease.

Recent studies have begun to elucidate the process leading to the generation of serum proteins such as $C$ reactive protein and $\alpha_{1}$ acid glycoprotein, showing the hepatic origin of these proteins, and that hepatic synthesis of these acute phase reactants is rapidly up-regulated in response to various cytokines released from inflammatory cells. In particular, the role of the mediators interleukin 1 (IL 1), tumour necrosis factor $\alpha$ (TNF $\alpha$ ), and interleukin 6 (IL 6) (monocytic hepatocyte stimulating factor) have been emphasised. ${ }^{6-11}$ In inflamed tissue, the generation of this family of polypeptides from macrophages is substantially enhanced. In the context of inflammatory bowel disease, the noted differences in circulating concentrations of acute phase proteins between Crohn's disease and ulcerative colitis may reflect qualitative differences in the cytokines produced in inflamed tissue, or again, reflect trivially, differences only in the number of macrophages involved in the inflammatory process.

We therefore investigated the ability of cells of the monocyte-macrophage lineage from patients with ulcerative colitis and Crohn's disease, to release the cytokines IL $1 \beta$ and TNF $\alpha$. We quantified release of these cytokines from peripheral blood monocytes during both active and quiescent disease, and compared the results with those from normal control subjects. 


\section{Methods}

\section{PATIENTS AND CONTROLS}

Three groups were investigated: group I, Crohn's disease, 22 patients comprising 11 men and 11 women (mean (SD) age, $41 \cdot 9(15 \cdot 1)$ years; range 23-69 years); group II, ulcerative colitis, 21 patients comprising 16 men and five women (mean age, $52 \cdot 2(19 \cdot 2)$ years; range $22-79$ years); group III, controls, 11 healthy individuals comprising six men and five women (mean age, 40.8 (13.2) years; range $27-65$ years). The diagnosis of ulcerative colitis or Crohn's disease was based on clinical, radiological, endoscopic, and biopsy findings.

\section{DISEASE ACTIVITY}

In Crohn's disease activity was assessed by a simple index of Crohn's disease activity, 0-15 (Harvey and Bradshaw, 1980). ${ }^{12}$ An index of $\leq 1$ was defined as corresponding to quiescent disease and one of $\geq 2$ to active disease. In this group, 11 patients had quiescent disease and 11 suffered from active disease. Ten patients with inactive disease had a simple index of 0 and one had a simple index of 1 . Those with active disease had a mean (SEM) simple index of $4.6(0.7)$; range 2-10. In terms of the extent of the disease, 12 patients had ileitis, seven ileocolitis, and three colitis.

Patients with ulcerative colitis were assessed as being in remission or having mild, moderate, or severe disease (Truelove and Witts, 1955). ${ }^{13}$ There were 10 patients in the ulcerative colitis group who had active disease and 11 patients had inactive disease, with one patient whose disease subsequently became active. Of the patients in the active group, six were mildly active and five had moderately active disease. In terms of disease distribution, four patients had pancolitis, 12 had left colon involvement (of which two had proctosigmoiditis, eight had involvement of the rectum, sigmoid, and descending colon, and two had involvement of the rectum, sigmoid, descending, and transverse colon), and five had disease limited to the rectum.

\section{TREATMENT}

In the Crohn's disease group, nine patients were not on treatment. Two patients were receiving sulphasalazine and five were being treated with 5 -aminosalicylic acid; one of these was also receiving prednisolone. One patient was receiving fluticasone propionate, four patients were receiving prednisolone alone, and one patient was treated with prednisolone and azathioprine. In the ulcerative group, three patients were not on treatment. Nine patients were receiving sulphasalazine and six were on treatment with 5-aminosalicylic acid; one of these was also receiving prednisolone. One patient received steroid enemas, one received prednisolone alone, and one received treatment with prednisolone and azathioprine. and stored at $-20^{\circ} \mathrm{C}$. Serum $\mathrm{C}$ reactive protein and serum $\alpha_{1}$ acid glycoprotein measurements were done by enzyme linked immunosorbent assay (ELISA). Briefly, polyvinyl 96-well microtitre plates (Dynatech, USA) were coated with goat anti-human $\mathrm{C}$ reactive protein (Miles Laboratories Inc) or goat anti-human $\alpha_{1}$ acid glycoprotein (Sigma) in $0.05 \mathrm{~mol} / \mathrm{l}$ sodium carbonate, $\mathrm{pH} 9.6$, overnight at $4^{\circ} \mathrm{C}$. These coated plates were then washed and incubated with serum samples and various dilutions of $C$ reactive protein (Behringwerke) or $\alpha_{1}$ acid glycoprotein (Sigma) for standard curves. Peroxidase conjugated rabbit anti-human $\mathrm{C}$ reactive protein or rabbit anti-human $\alpha_{1}$ acid glycoprotein followed by peroxidase conjugated swine antirabbit immunoglobulins were then added to the plates. After further incubation, the plates were washed and developed with orthophenylenediamine. The intensity of the colour was measured at $\mathrm{A} 492 \mathrm{~nm}$.

MONOCYTE SEPARATION AND INCUBATION

Twenty ml of EDTA treated blood were diluted 1:3 with Hanks' balanced salt solution (HBSS), and mononuclear cells were separated on a Isopaque-Ficoll density gradient (Nycomed). ${ }^{14}$ Peripheral blood mononuclear cells were collected from the interphase and washed twice, once in HBSS and the second wash in RPMI 1640 media (Gibco, UK). Cells were then resuspended in RPMI 1640 media supplemented with $10 \%(\mathrm{v} / \mathrm{v})$ heat inactivated fetal calf serum, $4 \mathrm{mmol} / \mathrm{l} \mathrm{L}$-glutamine, $100 \mathrm{IU}$ penicillin per $\mathrm{ml}$, $100 \mu \mathrm{g}$ streptomycin per $\mathrm{ml}$, and $25 \mathrm{mmol} / \mathrm{l}$ HEPES buffer (complete medium). The concentration of monocytes was adjusted to $2 \times 10^{6} / \mathrm{ml}$ by staining for peroxidase positive cells. The mononuclear preparation was then plated on 60 $\mathrm{mm}$ tissue culture plates (Nunclon) and these plates were incubated for two hours at $37^{\circ} \mathrm{C}$ in a $5 \% \mathrm{CO}_{2}: 95 \%$ air tissue culture incubator to allow the monocytes to adhere firmly to the plates. The non-adherent lymphocytes and platelets were removed by washings with warm serum free RPMI 1640 media to ensure pure monocytes were obtained. ${ }^{16}$ The viability of the adherent monocytes was greater than $95 \%$ and peroxidase staining of the non-adherent cells confirmed that the washing procedure did not significantly displace adherent monocytes.

\section{CYTOKINE GENERATION AND MEASUREMENT}

Monocyte cultures were divided into two groups with or without stimulation by $10 \mu \mathrm{g} / \mathrm{ml}$ lipopolysaccharide (Sigma). After incubation for 48 hours at $37^{\circ} \mathrm{C}$, conditioned media were collected, centrifuged, and stored at $-20^{\circ} \mathrm{C}$. Preliminary experiments had shown that 48 hours incubation in conditioned medium had the greatest effect in stimulating $\alpha_{1}$ acid glycoprotein synthesis and depressing albumin synthesis in cultures of HepG2 cells. An ELISA technique was employed to measure IL $1 \beta$ in monocyte conditioned media. In this assay system, various dilutions of recombinant human IL $1 \beta$ were used (British Bio-technology) for a standard curve. The antibodies employed were rabbit 
anti-recombinant human IL $1 \beta$ (Universal Biologicals, UK); goat anti-recombinant human IL $1 \beta$ (British Bio-technology, UK), which has no cross reactivity with IL $1 \alpha$, IL 2 , IL 6 , tumour necrosis factor alpha (TNF $\alpha$ ) or TNF $\beta$; and peroxidase conjugated donkey anti-goat IgG (Jackson Immunoresearch Lab, USA). TNF $\alpha$ in monocyte conditioned media was also measured by ELISA. ${ }^{17}$ The lower detection limit of the IL $1 \beta$ assay was $20 \mathrm{pg} / \mathrm{ml}$, and the TNF $\alpha$ assay $10 \mathrm{pg} / \mathrm{ml}$. There was no cross reaction between these two assays; and in addition IL 6 and IL 10 did not interfere with the assay.

\section{STIMULATION OF ACUTE PHASE RESPONSE IN HePG2 CELLS WITH MONOCYTE CONDITIONED MEDIUM}

For stimulation of acute phase response proteins, HepG2 cells were trypsinised and a suspension in $25 \mathrm{ml}$ complete medium at 100000 cells $/ \mathrm{ml}$ was established. Aliquots $(1 \mathrm{ml})$ were placed into 24 well tissue culture plates and HepG2 cells were allowed to reach confluence. Equal volumes of monocyte conditioned medium and fresh complete medium were added and incubated in a 5\% $\mathrm{CO}_{2}: 95 \%$ air tissue culture incubator. After 60 hours, supernatant media were collected and analysed for levels of secreted $\alpha_{1}$ acid glycoprotein

\section{STATISTICS}

Non-parametric procedures were employed for statistical significance testing. Comparisons between groups were assessed by KruskalWallis, Wilcoxon signed rank test, and the Mann-Whitney U-test. Correlation coefficients were calculated using Kendall rank correlation test.

\section{Results}

PERIPHERAL BLOOD MONOCYTES

The number of peripheral blood monocytes was mean (SEM) $3.2(0.6) \times 10^{5} / \mathrm{ml}$ for ulcerative colitis, $3.6(0.6) \times 10^{5} / \mathrm{ml}$ for Crohn's disease, and $3 \cdot 3(0 \cdot 3) \times 10^{5} / \mathrm{ml}$ for normal controls, with no significant differences between the three groups. However, among the patients with inflammatory bowel disease, those who had active inflammation $\left(4 \cdot 0(0 \cdot 7) \times 10^{5} / \mathrm{ml} ; \mathrm{p}<0.05\right.$ Wilcoxon) had greater monocyte counts than those without active disease $\left(2 \cdot 8(0 \cdot 2) \times 10^{5} / \mathrm{ml}\right)$. In patients with active ulcerative colitis $(4 \cdot 1$ $(1 \cdot 1) \times 10^{5} / \mathrm{ml} ; \mathrm{p}<0.01$ Wilcoxon) the number of peripheral blood monocytes is significantly higher than in patients with inactive disease $(2 \cdot 4$ $\left.(0 \cdot 3) \times 10^{5} / \mathrm{ml}\right)$. In active Crohn's disease $(3.9$ $\left.(1 \cdot 1) \times 10^{5} / \mathrm{ml}\right)$, the number of peripheral blood monocytes showed a similar trend compared with patients with inactive disease $(3 \cdot 2(0 \cdot 3) \times$ $105 / \mathrm{ml}$ ) but the difference did not reach statistical significance. tive colitis $(29 \cdot 2(3 \cdot 8) \mathrm{pg} / \mathrm{ml})$ was not statistically significantly different compared with values in normal controls $(29 \cdot 3(9 \cdot 8) \mathrm{pg} / \mathrm{ml})$.

Lipopolysaccharide stimulated IL $1 \beta$ generation in Crohn's disease $(592.3(277 \cdot 8) \mathrm{pg} / \mathrm{ml}$; $\mathrm{p}<0.05$ Mann-Whitney) was significantly higher than in ulcerative colitis $(114 \cdot 7(26 \cdot 1) \mathrm{pg} / \mathrm{ml})$ and normal controls $(101.2(43.6) \mathrm{pg} / \mathrm{ml})$, with a dramatic increase in patients with active disease $(1078.0(536.7) \mathrm{pg} / \mathrm{ml} ; \mathrm{p}<0.05$ Mann-Whitney) compared with inactive disease $(106.6(16.9) \mathrm{pg}$ / $\mathrm{ml}$ ).

Lipopolysaccharide stimulated IL $1 \beta$ generation in ulcerative colitis is not significantly different from that in normal controls, although in active disease $(129 \cdot 1(43.6) \mathrm{pg} / \mathrm{ml})$ a slight increase was observed.

\section{RELATION BETWEEN DISEASE ACTIVITY, DISEASE}

SITE, AND IL $1 \beta$ GENERATION

A significant positive correlation was found between lipopolysaccharide stimulated IL $1 \beta$ generation and disease activity as assessed by a simple index of Crohn's disease activity $(r=0 \cdot 47$, $\mathrm{p}<0.005$ Kendall's rank correlation). When results in Crohn's disease were analysed and classified according to the extent of the disease, both spontaneous and lipopolysaccharide stimulated IL $1 \beta$ generations were raised in patients with ileocolonic and colonic disease compared with patients with ileal disease, although the differences did not reach statistical significance.

In ulcerative colitis, a significant positive correlation was also found between lipopolysaccharide stimulated IL $1 \beta$ generation and disease activity $(r=0.55, p<0.005$ Kendall's rank correlation). When results were analysed and classified according to the extent of disease, neither spontaneous or lipopolysaccharide stimulated IL $1 \beta$ generations in patients with total colonic involvement was significantly different to values in patients without total colonic involvement.

\section{IN VITRO PRODUCTION OF TNF $\alpha$}

Spontaneous release of TNF $\alpha$ in Crohn's disease $(52 \cdot 2(20 \cdot 1) \mathrm{pg} / \mathrm{ml})$ was not significantly different to the values in ulcerative colitis patients $(25 \cdot 2$ $(7 \cdot 7) \mathrm{pg} / \mathrm{ml})$ and normal controls $(87 \cdot 2(32 \cdot 1) \mathrm{pg} /$ $\mathrm{ml})$.

Lipopolysaccharide stimulated TNF $\alpha$ generation in Crohn's disease $(177 \cdot 5(66 \cdot 1) \mathrm{pg} /$ $\mathrm{ml})$ was similar to that in normal controls $(196 \cdot 3$ $(50.5) \mathrm{pg} / \mathrm{ml})$, although patients with active disease $(286.8(125 \cdot 4) \mathrm{pg} / \mathrm{ml})$ showed higher but not statistically significant levels of lipopolysaccharide stimulated TNF $\alpha$ than normal controls.

Lipopolysaccharide stimulated TNF $\alpha$ generation in ulcerative colitis $(59.4(23.9) \mathrm{pg} /$ $\mathrm{ml}$ ) was significantly lower than in Crohn's disease ( $p<0.05$ Mann-Whitney) and in normal controls ( $p<0.02$ Mann-Whitney). 
between lipopolysaccharide stimulated TNF $\alpha$ generation and disease activity in Crohn's disease as assessed by a simple index of Crohn's disease activity $(r=0.67, p<0.001$ Kendall's rank correlation). When results were analysed by classifying Crohn's disease according to the extent of the disease, both spontaneous and lipopolysaccharide stimulated TNF $\alpha$ generations in patients with ileocolonic and colonic disease were not significantly different to values in patients with ileal disease alone.

In ulcerative colitis, a significant positive correlation was also found between lipopolysaccharide stimulated TNF $\alpha$ generation and disease activity $(r=0.80, p<0.001$ Kendall's rank correlation). When results were analysed and classified according to the extent of disease, both spontaneous and lipopolysaccharide stimulated TNF $\alpha$ generations in patients with total colonic involvement were not significantly different to values in patients without total colonic involvement.

\section{CORRELATIONS OF CYTOKINE GENERATION WITH} SERUM C REACTIVE PROTEIN AND $\alpha_{1}$ ACID GLYCOPROTEIN

Serum $C$ reactive protein values in the patients with Crohn's disease varied between $0.5 \mathrm{mg} / \mathrm{l}$ and $225.3 \mathrm{mg} / \mathrm{l}$ (mean $24.8 \mathrm{mg} / \mathrm{l}$ ). Those in the patients with ulcerative colitis varied between $0.5 \mathrm{mg} / \mathrm{l}$ and $77.2 \mathrm{mg} / \mathrm{l}$ (mean $11.7 \mathrm{mg} / \mathrm{l}$ ).

Statistically significant but weak correlations were found between serum $C$ reactive protein and lipopolysaccharide stimulated IL $1 \beta$ and TNF $\alpha$ production in Crohn's disease, and between serum $C$ reactive protein and spontaneous IL $1 \beta$ production in ulcerative colitis (Table I).

Serum $\alpha_{1}$ acid glycoprotein concentrations in the patients with Crohn's disease varied between $98.7 \mathrm{mg} / \mathrm{dl}$ and $433.3 \mathrm{mg} / \mathrm{dl}$ (mean $202.1 \mathrm{mg} / \mathrm{dl}$ ). Serum $\alpha_{1}$ acid glycoprotein values in the patients with ulcerative colitis varied between $69.6 \mathrm{mg} / \mathrm{dl}$ and $507.6 \mathrm{mg} / \mathrm{dl}$ (mean $167.9 \mathrm{mg} / \mathrm{dl}$ ).

Statistically significant but weak correlations were found between serum $\alpha_{1}$ acid glycoprotein and lipopolysaccharide stimulated IL $1 \beta$ and TNF $\alpha$ production in Crohn's disease, and between serum $\alpha_{1}$ acid glycoprotein and spontaneous IL $1 \beta$ production in ulcerative colitis.

CORRELATION OF CYTOKINE GENERATION WITH IN VITRO $\alpha_{1}$ ACID GLYCOPROTEIN SYNTHESIS

In vitro $\alpha_{1}$ acid glycoprotein synthesis in response to monocyte conditioned medium from patients with Crohn's disease, varied between $185.4 \mathrm{ng} / \mathrm{ml}$ and $757 \cdot 7 \mathrm{ng} / \mathrm{ml}$ (mean $339.5 \mathrm{ng} / \mathrm{ml}$ ) for monocytes without lipopolysaccharide, and $231.2 \mathrm{ng} / \mathrm{ml}$ and $1372.5 \mathrm{ng} / \mathrm{ml}$ (mean $486.9 \mathrm{ng}$ / $\mathrm{ml})$ with lipopolysaccharide.

In vitro $\alpha_{1}$ acid glycoprotein synthesis in response to monocyte conditioned medium from patients with ulcerative colitis, varied between $190.9 \mathrm{ng} / \mathrm{ml}$ and $586.7 \mathrm{ng} / \mathrm{ml}$ (mean $308.9 \mathrm{ng} / \mathrm{ml}$ ) for monocytes without lipopolysaccharide, and $241.0 \mathrm{ng} / \mathrm{ml}$ and $634.5 \mathrm{ng} / \mathrm{ml}$ (mean $436.1 \mathrm{ng} / \mathrm{ml}$ ) with lipopolysaccharide.

Statistically significant correlations were found between the in vitro generation of $\alpha_{1}$ acid glycoprotein production in response to conditioned medium and the IL $1 \beta$ concentration in those medium when the conditioned medium was obtained in the absence but not in the presence of lipopolysaccharide, for both Crohn's disease and ulcerative colitis (Table II). Correlations with TNF $\alpha$ in the medium were either weaker (in Crohn's disease) or absent (ulcerative colitis).

\section{Discussion}

Monocytes-macrophages play a major role in the pathogenesis of an inflammatory response. This study confirms that in active inflammatory bowel disease there is an increased number of circulating monocytes, the precursors of tissue macrophages, and accords with reports that in active disease (both Crohn's disease and ulcerative colitis) there is an increase in the turnover of peripheral blood monocytes. ${ }^{18-19}$ These cells are in a state of activation as judged by increased motility and phagocytosis, spontaneous giant cell formation, increased superoxide anion $\left(\mathrm{O}_{2}\right)$ generation, and by the release of lysosomal enzymes. ${ }^{20-22}$ Activated monocytes also produce cytokines, which are a series of biologically active polypeptides fulfilling the roles of inflammatory mediators. The major finding of this study is that there is a difference in the profile of cytokines released by peripheral blood monocytes from patients with Crohn's disease compared with patients with ulcerative colitis, suggested but not established by previous workers. $^{23-25}$

TABLE I Correlation of in vitro cytokine generation with serum $C$ reactive protein and serum $\alpha_{1}$ acid glycoprotein. rvalues - Kendall rank correlation coefficients

\begin{tabular}{|c|c|c|}
\hline $\begin{array}{l}\text { Cytokine } \\
\text { generation }\end{array}$ & $\begin{array}{l}\text { C reactive } \\
\text { protein }\end{array}$ & $\begin{array}{l}\alpha_{1} \text { acid } \\
\text { glycoprotein }\end{array}$ \\
\hline $\begin{array}{l}\text { Interleukin } 1 \beta \\
\text { Crohn's disease: } \\
\text { Spontaneous } \\
\text { Lipopolysaccharide } \\
\text { stimulated } \\
\text { Ulcerative colitis: } \\
\text { Spontaneous } \\
\text { Lipopolysaccharide } \\
\text { stimulated } \\
\text { Tumour necrosis factor } \alpha \\
\text { Crohn's disease: } \\
\text { Spontaneous } \\
\text { Lipopolysaccharide } \\
\text { stimulated } \\
\text { Ulcerative colitis: } \\
\text { Spontaneous } \\
\text { Lipopolysaccharide } \\
\text { stimulated }\end{array}$ & $\begin{array}{l}\text { NS } \\
r=0.35 p<0.05 \\
r=0.42 p<0.01 \\
\text { NS }\end{array}$ & $\begin{array}{l}\text { NS } \\
r=0.30 p<0.05 \\
r=0.35 p<0.05 \\
\text { NS }\end{array}$ \\
\hline
\end{tabular}

TABLE II Correlation of cytokine generation in monocyte conditioned medium with $\alpha_{1}$ acid glycoprotein synthesis by HepG2 cells in response to conditioned medium. $r$ values Kendall rank correlation coefficients

\begin{tabular}{|c|c|}
\hline Cytokine generation & $\alpha_{1}$ acid glycoprotein \\
\hline \multicolumn{2}{|l|}{ Interleukin $1 \beta$} \\
\hline \multicolumn{2}{|l|}{ Crohn's disease: } \\
\hline Spontaneous & $r=0.68(p<0.001)$ \\
\hline Lipopolysaccharide stimulated & NS \\
\hline \multicolumn{2}{|l|}{ Ulcerative colitis: } \\
\hline Spontaneous & $\mathrm{r}=0.77(\mathrm{p}<0.001)$ \\
\hline Lipopolysaccharide stimulated & NS \\
\hline \multicolumn{2}{|l|}{ Tumour necrosis factor a } \\
\hline \multicolumn{2}{|l|}{ Crohn's disease: } \\
\hline Spontaneous & $\mathrm{r}=0.37(\mathrm{p}<0.05)$ \\
\hline Lipopolysaccharide stimulated & $\mathrm{r}=0.29(\mathrm{p}<0.05)$ \\
\hline \multicolumn{2}{|l|}{ Ulcerative colitis: } \\
\hline Spontaneous & NS \\
\hline Lipopolysaccharide stimulated & NS \\
\hline
\end{tabular}


We found that lipopolysaccharide stimulated IL $1 \beta$ generation from peripheral blood monocytes in patients with Crohn's disease was much greater than in those with ulcerative colitis or normal controls. In active Crohn's disease, the generation of IL $1 \beta$ increased dramatically and showed a significant positive correlation with a simple index of Crohn's disease activity. In ulcerative colitis, IL $1 \beta$ generation by lipopolysaccharide stimulated monocytes did not differ significantly from values in normal controls and showed only a slight increase in active disease. Thus, monocytes in Crohn's disease compared with ulcerative colitis show a greater potential for production of this cytokine. With regard to TNF $\alpha$, lipopolysaccharide stimulated monocytes in Crohn's disease produced significantly higher values than those in ulcerative colitis. Patients with active Crohn's disease also released higher levels of lipopolysaccharide stimulated TNF $\alpha$ than healthy controls, although the difference is not statistically significant, and the results therefore suggest that these differences include a relative inability of monocytes from patients with ulcerative colitis to generate TNF $\alpha$.

Generation of cytokines will lead to inflammation. The local effects within the tissues of differing profiles of cytokines in two forms of inflammatory bowel disease lie outside the scope of this report, but in view of the known amplificatory effects of monocyte derived cytokines on other cellular mediators of inflammation, one can speculate that differing elements of the inflammatory response may be amplified in Crohn's disease compared with ulcerative colitis. In this study, we have examined a remote action of cytokines, their effect on the acute phase protein generation from the liver. Synthesis and secretion of many liver proteins are modulated by cytokines, leading to changes in acute phase protein serum concentrations in inflammation. The changes include a moderate increase in serum concentrations of specific proteins such as $\alpha_{1}$ acid glycoprotein and proteinase inhibitors like $\alpha_{1}$ antichymotrypsin and a decrease in albumin. $\mathrm{C}$ reactive protein shows a more pronounced response by a two to threefold log increase during this response.

These changes in serum proteins characteristic of an acute phase response occur in inflammatory bowel disease. $\mathrm{C}$ reactive protein shows more noticeable changes in Crohn's disease than in ulcerative colitis. The data reported here accord with the suggestion that a more enhanced acute phase response in Crohn's disease may reflect differences in the profile of cytokines produced by macrophages from patients with this disorder. This is suggested by the presence of significant though low correlations between IL $1 \beta$ and TNF $\alpha$ release and with serum C reactive protein and serum $\alpha_{1}$ acid glycoprotein concentrations in patients with Crohn's disease. Our studies correlating cytokine generation with the ability of conditioned medium to stimulate $\alpha_{1}$ acid glycoprotein synthesis in vitro suggest that IL $1 \beta$ is a major contributor to the control of this particular acute phase reactant in inflammatory bowel disease. Unfortunately the liver cell line we studied does not express $C$ reactive protein.

While suggesting that the greater expression of acute phase response proteins in Crohn's disease is induced by the cytokines IL 1 and TNF $\alpha$, this study does not exclude the involvement of other mediators, particularly IL 6 which is recognised to be a major modulator of the acute phase response. ${ }^{26}$ Reports on IL 6 production by patients with inflammatory bowel disease have been conflicting. ${ }^{27}$ Some observations on IL 6 production by peripheral blood mononuclear cells have reported no significant difference between ulcerative colitis, Crohn's disease patients, and normal controls. ${ }^{28}$ Others report that in Crohn's disease both IL 6 plasma concentrations and lipopolysaccharide stimulated IL 6 generation by peripheral blood monocytes are raised compared with values in normal controls, but do not show data in ulcerative colitis. ${ }^{29}$ There are complex inter-relations between these cytokines, which may act directly or indirectly. Thus IL 1 can induce expression of TNF ${ }^{30}$ and is also a strong inducer of IL 6 release. ${ }^{31}{ }^{32}$ TNF can also induce release of IL $1^{33}$ and act as a potent stimulus for the production of IL $6,3+35$ which may then induce the synthesis of acute phase proteins by hepatocytes. Perlmutter et $a l^{36}$ found that IL 1 and TNF individually increased the synthesis of $\alpha_{1}$ acid glycoprotein. Andus et al showed in an in vitro study that IL $1 \beta$ and TNF $\alpha$ lead to a 20 fold increase in $\alpha_{1}$ acid glycoprotein mRNA in the presence of dexamethasone. IL 6 , on the other hand, is a much weaker stimulator of $\alpha_{1}$ acid glycoprotein synthesis. ${ }^{9}$ Each of IL $1 \beta$, TNF $\alpha$, and IL 6 has been shown experimentally to modulate $C$ reactive protein production. ${ }^{37-40}$

The study of acute phase proteins in inflammatory bowel disease is relevant from two points of view. These proteins provide valuable laboratory parameters for assessing disease activity, and this has been the main concern in this study. The physiological relevance of acute phase reactant is not completely understood. A major function may be to counterbalance indirectly the toxic actions of mediators of inflammation on tissue damage. ${ }^{+1-43}$

Since identical numbers of monocytes were employed for each patient in this study, it seems that the differences in cytokine profile reported here between patients with Crohn's disease and ulcerative colitis reflect an intrinsic, perhaps genetically determined, difference in the ability to produce cytokines rather than a quantitative difference in the number of macrophages activated at the disease site. Although the data obtained were from studying isolated peripheral blood monocytes, relevance to the gut may be inferred since peripheral blood monocytes are precursors of tissue macrophages. Monocytes thus provide an opportunity to study the mononuclear phagocytes cell line before the monocytes migrate from the blood into the bowel mucosa where they became activated. These immunological responses seen in the peripheral blood are events that mirror systemic activation in the gut. Mucosal cytokine production is an important aspect of the mucosal immune system which plays a key role in gut inflammation in both Crohn's disease and ulcerative colitis. These findings add further evidence to support the immunological basis of the pathogenesis of inflammatory bowel disease. They do not con- 
flict with the view that Crohn's disease and ulcerative colitis are part of a spectrum of a single disease process manifesting as different clinical entities, but suggest that the difference in inflammatory events reflects inter alia genetically determined properties of the macrophage series.

This study was supported by a project grant from The Nationa Association for Colitis and Crohn's Disease. The authors wish to thank Dr W A Buurman of University of Limburg, Mastricht, The Netherlands, for providing murine monoclonal anti-human The Netherlands, for providing murine monoclonal anti-human TNF $\alpha(61 E 71)$ and rabbit polyclonal anti-human TNF $u$ National Institute for Biological Standards and Control, South Mimms, Potters Bar, Hertfordshire, England, for the gift of
recombinant human TNF $\alpha$ (code 87/650). Gastroenterology registrars for their clinical assistance in this study.

1 Allan R, Hodgson HJF. Inflammatory bowel disease. In Pounder RE, ed. Recent advances in gastroenterology. London: Churchill Livingstone, 1988; 7: 1-21.

2 Fagan EA, Dyck RF, Maton PN, Hodgson HJF, Chadwick VS, Aviva Petri, et al. Serum levels of C-reactive protein in VS, Aviva Petri, et al. Serum levels of C-reactive protein in
Crohn's disease and ulcerative colitis. Eur f Clin Invest 1982 ; 12: $351-9$.

3 Chambers RE, Stross P, Barry RE, Whicher JT. Serum amyloid A protein compared with $\mathrm{C}$-reactive protein, alpha 1-antichymotrypsin and alpha 1-acid glycoprotein as monitor of inflammatory bowel disease. Eur $\mathcal{f}$ Clin Inves 1987; 17: 460-7.

4 Adeyemi EO, Neumann S, Chadwick VS, Hodgson HJF, Pepys MB. Circulating human leucocyte elastase in patient with inflammatory bowel disease. Gut 1985; 26: 1306-11.

5 Weeke B, Jarnum S. Serum concentration of 19 serum proteins in Crohn's disease and ulcerative colitis. Gut 1971; 12: 297-302.

6 Mizel SB. The interleukines. FASE B f 1989; 3: 2379-88

7 Balkwill FR. Tumour necrosis factor. Br Med Bull 1989; 45 : 389-400.

8 Darlington GJ, Wilson DR, Lachman LB. Monocyteconditioned medium interleukine-1, and tumor necrosis factor stimulate the acute phase response in human hepatoma cells in Vitro. $\mathcal{F}$ Cell Biol 1986; 103: 787-93.

9 Andus T, Geiger T, Hirano T, Kishimoto T, Heinrich PC. Action of recombinant human interleukine 6 , interleukine $1 \beta$ and tumor necrosis factor $\alpha$ on mRNA induction of acutephase proteins. Eur f Immunol 1988; 18: 739-46.

10 Baumann $\mathrm{H}$. Hepatic acute phase reaction in vivo and in vitro. In Vitro Cell Dev Biol 1989; 25: 115-26.

11 Baumann H, Gauldie J. Regulation of hepatic acute phase plasma protein genes by hepatocyte stimulating factors and other mediators of inflammation. Mol Biol Med 1990; 7 : $147-59$.

12 Harvey RF, Bradshaw JM. A simple index of Crohn's-disease activity. Lancet 1980 ; i: 514

13 Truelove SC, Witts LJ. Cortisone in ulcerative colitis. BMF 1955; 2: 1041-144.

14 Boyum A. Isolation of mononuclear cells and granulocyte from human blood. Scand $\mathcal{F}$ Clin Lab Invest 1968; 21 (suppl 97): 77-88.

15 Boyum A. Separation of lymphocytes, granulocytes, and monocytes from human blood using iodinated density gradient media. Meth Enzymol 1984; 108: 88-102.

16 Woloski BMRNJ, Fuller GM. Hepatocyte-stimulating factor. Methods Enzymol 1988; 163: 594-6.

17 Debets JMH, van der Linden CJ, Spronken IEM, Buurman WA. T Cell-Mediated production of tumour necrosis factor$\alpha$ by monocytes. Scand F Immunol 1988; 27: 601-8.

18 Mee AS, Berney J, Jewell DP. Monocytes in inflammatory bowel disease absolute monocyte counts. F Clin Pathol 1980 33: $917-20$

19 Meuret G, Bitzi A, Hammer B. Macrophage turnover in Crohn's disease and ulcerative colitis. Gastroenterolog 1978; 74: 501-3.

20 Hermanowicz A, Gibson PR, Jewell DP. The role of phagocytes in inflammatory bowel disease. Clin Sci 1985; 69: 241-9.

21 Miura M, Hiwatashi N. Impaired monocyte macrophages function in patients with Crohn's disease. 7 Clin Lab Immunol 1987; 24: 167-70.

22 O'Brien CJ, Brumwell P, Clark A, Holdsworth CD. Monocyte activity in relation to disease activity in patients with Crohn's disease. Gut 1990; 31: A1182.
23 Miura $M$, Hiwatashi N. Cytokine production in inflammatory bowel disease. 7 Clin Lab Immunol 1985; 18: 81-6.

24 Satsangi J, Wolstencroft RA, Cason J, Ainley CC, Dumonde DC, Thompson RPH. Interleukine 1 in Crohn's disease. Clin Exp Immunol 1987; 67: 594-605.

25 Suzuki Y. Tobin A, Quinn D, Whelan A, O'Morain C. Interleukin 1 in inflammatory bowel disease. Gastroenterology 1989; 96: A498.

26 Gauldie J, Richards C, Harnish D, Lansdorp P, Baumann H. Interferon $\beta_{2} / \mathrm{B}$ cell stimulatory factor type 2 shares identity with monocyte-derived hepatocyte-stimulating factor and regulates the major acute phase protein in liver cells. Proc Natl Acad SciUSA 1987; 84: 7251.

27 Niida N, Murata Y, Suzuki K, Ishizuka K, Saito H, Munakata $\mathrm{A}$, et al. Increased interleukine- 6 synthesis by peripheral blood mononuclear cells from patients with ulcerative colitis but not with Crohn's disease. Gastroenterology 1990; 98: A466.

28 Mahida YR, Kurlak L, Gallagher A, Hawkey CJ. Circulating and tissue interleukin 6 (IL 6) levels in inflammatory bowel disease. Gastroenterology 1990; 98: A461.

29 Andus T, Gross V, Krumm D, Hosp J, David M, Gerok W, et al. Enhanced interleukine-6 synthesis during active Crohn's disease [Abstract]. Inflammatory Bowel Disease: Progress in basic research and clinical implication. 1990; Falk
Pron's Progress in basic research and clinical
symposium 60: Kluwer, 1991; 46.

30 Philip R, Epstein LB. Tumour necrosis factor as immunomodulatory and mediator of monocyte cytotoxicity induced by itself, $\tau$-interferon and interleukine-1. Nature 1986; 323 : 86-9.

31 Sironi M, Breviario F, Proserpio P, Biondi A, Vecchi A, Van Damme J, et al. IL-1 stimulates IL-6 production in endothelial cells. F Immunol 1989; 142: 549-53.

32 Van Damme J, Opdenakker G, Simpson RJ, Rubira MR, Cayphas S, Vink A, et al. Identification of the human $26 \mathrm{kD}$ protein, interferon $\beta_{2}$ (IFN- $(3$, ) as a $B$ cell hybridoma/

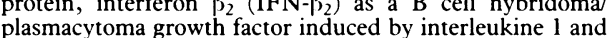
plasmacytoma growth factor induced by interleukine

33 Dinarello CA, Canon JG, Wolff SM, Bernheim HA, Beutler B, Cerami A, et al. Tumor necrosis factor (cachectin) is an Cerami A, et al. Tumor necrosis factor (cachectin) is an endogenous pyrogen and induces
1. $\mathcal{E}$ Exp Med 1986; 163: 1433-50

34 Kohase M, Henriksen-Destefano D, May LT, Vilcek J, Sehgal PB. Induction of $\beta 2$-interferon by tumor necrosis factor: A homeostatic mechanism in the control of cell population. Cell 1986; 45: 659-66.

35 Defilippi P, Poupart P, Tavernier J, Fiers W, Content J. Induction and regulation of mRNA encoding $26-\mathrm{kDa}$ protein in human cell lines treated with recombinant human tumor necrosis factor. Proc Natl Acad Sci USA 1987; 84: 4557-61.

36 Perlmutter DH, Dinarello CA, Punsal PI, Colten HR. Cachectin/Tumor necrosis factor regulates hepatic acuteCachectin/Tumor necrosis factor regulates hepatic acute

37 Goldman ND, Liu T-y. Biosynthesis of human C-reactive protein in cultured hepatoma cells is induced by a monocyte factor(s) other than interleukine-1. F Biol Chem 1987; 262 2363-8.

38 Ganapathi MK, Schultz D, Mackiewicz A, Samols D, Hu S-I, Brabenec A, et al. Heterogenous nature of the acute phase response. Differential regulation of human serum amyloid $\mathrm{A}, \mathrm{C}$-reactive protein and other acute phase proteins by cytokines in Hep 3B cells. 7 Immunol 1988; 141: 564-9.

39 Moshage HJ, Roelofs HMJ, van Pelt JF, Hazenberg BPC, van Leeuwen MA, Limburg PC, et al. The effect of interleukin1 , interleukin- 6 and its inter-relationship on the synthesis of serum amyloid $A$ and $C$-reactive protein in primary cultures serum amyloid A and C-reactive protein in primary cultures of adult human hep

40 Michie HR, Spriggs DR, Manogue KR, Sherman ML, Revhaug A, O'Dwyer ST, et al. Tumor necrosis factor and endotoxin induce similar metabolic responses in human beings. Surgery 1988; 104: 280-6.

41 Pepys MB, Baltz BL. Acute phase proteins with special reference C-reactive protein and related proteins (pentraxins) and serum amyloid A protein. Adv Immunol 1983; 34: 141-212.

42 Robey FA, Jones KD, Tanaka T, Liu LY. Binding of C-reactive protein to chromatin and nucleosome core particles. A possible physiological role of $C$-reactive protein. particles. A possible physiological

43 Bennett $M$, Schmid K. Immunosuppression by human plasma $\alpha_{1}$-acid glycoprotein: importance of the carbohydrate $\alpha_{1}$-acid glycoprotein: importance of the carbo
moiety. Proc Natl Acad SciUSA 1980; 77: 6109-13. 